\title{
Foreign Direct Investment (FDI) and Nigerian Economic Growth
}

\section{Theophilus Okonkwo Okegbe, Raymond Asika Ezejiofor, Darlington Ifeanyi Ofurum}

Department of Accountancy, Faculty of Management Sciences, Nnamdi Azikiwe University, Awka, Nigeria

Email address:

to.okegbe@unizik.edu.ng(T. O. Okegbe),thaddray4life@yahoo.com(R. A. Ezejiofor),christmasofurum8019@gmail.com(D. I. Ofurum)

\section{To cite this article:}

Theophilus Okonkwo Okegbe, Raymond Asika Ezejiofor, Darlington Ifeanyi Ofurum. Foreign Direct Investment (FDI) and Nigerian Economic Growth. International Journal of Accounting, Finance and Risk Management. Vol. 4, No. 1, 2019, pp. 15-23.

doi: $10.11648 /$ j.jjafrm.20190401.12

Received: December 26, 2018; Accepted: January 25, 2019; Published: March 14, 2019

\begin{abstract}
This study evaluated the extent to which Foreign Direct Investment (FDI) has contributed to the Gross Domestic Product (GDP) in Nigeria from 2000 to 2017. In the course of this study, three hypotheses were formulated in line with the objectives of the study. Ex-Post Facto research design was employed for the study. Regression analysis technique was adopted with the aid of E-view version 9.0 in testing the hypotheses. The study revealed that foreign direct investment on financial sector has positive and significantly affected Gross Domestic Product in Nigeria. It also showed that Foreign Direct Investment on oil sector has positive and significantly affected Gross Domestic Product in Nigeria. Another finding is that Foreign Direct Investment on non-oil sector has positive and significantly affected Gross Domestic Product in Nigeria. the study therefore conclude that inflow of FDI into the Nigerian economy for the stipulated period this research was carried out (2000-2017), showed that FDI was a major contributor to economic growth of the nation Based on the findings, the researcher recommended among other things that Policy makers should devise strategies to increase the FDI on financial sector and offer incentive for long investing and listing on the stock market so that the main objective of the government to stimulate growth will be fulfilled.
\end{abstract}

Keywords: Foreign Direct Investment, Gross Domestic Product, Oil Sector and Financial Sector

\section{Introduction}

The importance of foreign direct investment (FDI) in the economies of third world nations like Nigeria is to promote growth and development in the host country. This is important because according to the International Monetary Fund, FDI promotes growth and economic development by transferring technology, skills and innovation [1]. FDI also assist in developing counties to acquire advanced technology and critical managerial skills which can increase productivity locally, create additional jobs, lower production costs and provide workers with higher wages [2]. In addition, FDI helps developing countries in supplementing their domestic savings by making available capital from overseas which is very important because domestic capital markets in such countries are usually inadequate for the financing of the corporate sector [3]. Recognizing these benefits, developing countries have generally eased restrictions on FDI since the early 1980s. Research has also shown that most developing countries including Nigeria have not appreciate Foreign Direct Investment (FDI) as a source of external financing of the economy due to a non conducive investment climate and the attitude of the host nations [4]. According to Oba and Onuoha the Nigerian government has been mobilizing foreigners to invest in Nigeria but factors such as infrastructures, poor financial system, corruption, security challenges, etc, have continued to hamper the growth of the FDI in the country [5]. Makki and Somwaru showed that foreign direct investment contributes toward advancing and significantly impact on economic growth in Nigeria [6]. Wang found that FDI contribute to economic growth [7]. Liu, Burridge, and Sinclair found a two-way relationship between FDI and economic growth [8].

In other hand, Ayanwale noted that the relationship between foreign direct investment and economic growth is not so clear [9]. Carkovic and Levine in their study concluded that exogenous component of FDI does not exert a robust positive influence on economic growth [10]. 
Benzuidenhout found negative relationship between FDI and economic growth [11]. Akinlo found that foreign capital has a small and non-statistical significant effect on economic growth in Nigeria [12]. Lall concluded that the contribution of FDI to economic growth depends on many factors and it varies over time and from one host country to another [13].

In most African countries, inadequate resource to finance long-term investment is a major problem [14]. This lack of investible funds is a big setback to economic growth and this is making it increasingly difficult to achieve the millennium development goals (MDGs) by 2015 as set by the United Nations. Foreign direct investment is seen as a major source of getting the required funds for investments hence most African countries offer incentives to encourage FDI [15].

Based on theoretical and analytical findings, there are different views by researchers on the contributions of FDI to economic growth, some are of a view that FDI as a very important tool for economic growth especially in the less developed countries (LDCs) but some scholars claimed that the contribution of FDI to economic development is not as pronounced as most people believe. Yet some scholars think FDI has no positive contribution to the economic growth of the host country. There has been no consensus opinion on FDI and economic growth. They therefore opined that there is the need to carry out more study on their relationship.

Considering the wide range of empirical studies on how foreign direct investment affects economic growth and development of Nigeria, one cannot draw conclusions from it with minimal acceptable level of confidence due to uncertainty in their findings. Therefore, there is need for further studies to be carried out on the effects of FDI on growth of Nigerian economy.

Objective of the Study

The major objective of this study is to determine the effect of foreign direct investment (FDI) on growth of Nigerian economy.

The specific objectives are:

1. To ascertain the effect of Foreign Direct Investment in financial sector on growth of Nigerian economy.

2. To determine the effect of Foreign Direct Investment in oil sector on growth of Nigerian economy.

3. To evaluate the effect of Foreign Direct Investment in non-oil sector on growth of Nigerian economy.

\section{Review of Related Literature}

\subsection{Conceptual Review}

According to Ogunleye, Foreign direct investment involves a business or production investment by a company to one or more countries. FDI enables host countries to achieve economic growth through investments that outweighs that of the host country's local investment [16].

International Monetary Fund defined foreign direct investment as an investment made to acquire lasting or longterm interest in enterprises operating outside of the economy of the investor." Barry described investment as direct because the investor, which could be a foreign person, company or group of entities, is seeking to control, manage, or have significant influence over the foreign enterprise [17]. Liu [8] predicted longitudinal relationship between FDI, trade and the economic growth in China. By using the data for 19811997 fiscal years, they found a two-way relationship between FDI, economic growth and import.

Foreign Direct investment can also be describes as an investment made by an investor or enterprises in another enterprises or equivalent in voting power or other means of control in another country with the aim to manage the investment and maximize profit. This investment involves not only the transfer of fund but also the transfer of physical capital, technique of production, managerial and marketing expertise, product advertising and business practice with the aim to make profit [18].

In the same vein, Obiwona further argued that FDI helps developing countries to gain access to foreign markets for goods and services for the people of the recipient country [19]. Shawn stated that Foreign Direct Investment is not the same with portfolio transfers (e.g. moving financial capital to foreign bank accounts) this is known as indirect investment. (However, if there is a portfolio transfer that leads to a foreign investor controlling a management share in the company, then this may be considered Foreign Direct Investment because of the transfer of ownership.) [20]. However, Aremu [21] sees foreign direct investment as investment in capital stock or asset of a country by another country or firm.

Ayanwale [9] offered an expanded explanation of the operational meaning of FDI as ownership of at least $10 \%$ of the ordinary shares or voting stock in a foreign enterprise. Thus, ownership of $10 \%$ ordinary shares is the criterion for the existence of a direct investment relationship while ownership of less than $10 \%$ is recorded as portfolio investment. Annaek defined Foreign Direct Investment as the process whereby people in one country obtain ownership of assets for the purpose of gaining control over the production, distribution and other activities of a firm in a foreign country [22].

HarunaDanja states that FDI and international capital flows as closing the savings gap in developing countries [23]. Foreign direct investment (FDI) has been regarded to be among the fastest growing economic activities around the globe. The FDI flows across the globe has risen sharply, from an annual average of US\$142 billion during the period of 1985-1990 to over US\$385 billion in the year 1996 and then it made a record by reaching a record of US\$1.9 trillion in the year 2007 [24]. The developing countries are not an exception to this. These countries increase their annual share out of total world FDI from $15 \%$ in 1990 to $30 \%$ in 2006 and then to $37 \%$ in the year 2008 [24]. The increasing FDI flows to developing countries since 1990 indicates that multinational companies have considered these host countries as the profitable investment destinations [25]. For developing countries as well FDI plays a significant role as a source of finance. FDI plays a very important role in enhancing the 
welfare of host country due to benefits related to new innovation, new technology, new managerial techniques, development of skills, increased capital, creation of job opportunities and improvement in the working condition of employees and development of industrial sector in the host country [26].

FDI has empirically been found to stimulate economic growth by a number of researchers; Borensztein, De Gregoria and Lee submits that FDI has been important in explaining china's economic growth [27], while Blomstrom, Lipsey and Zegan reported that positive effect on economic growth, but there seems to be a threshold level of income above which FDI has positive effect on economic growth and below which it does not [28]. The explanation was that only those countries that reached a certain income level that can absorb new technologies and benefit from technology diffusion and thus reap the extra advantages that FDI can offer. Previous works suggest human capital as one of the reasons for the differential response to FDI at different levels of income. This is because it takes a well-educated population to understand and spread the Benefits of new innovations to the whole economy. The neo-classical economists argue that FDI influences economic growth by increasing the amount of capital per income. However, because of diminishing returns to capital, it does not influence long-run economic growth.

\subsection{Review of Empirical Studies}

There have been some studies on foreign direct investment and growth in Nigeria with varying results and submissions. For instance, Makki and Somwaru examined the role foreign direct investment and trade in economic growth of developing countries within the endogenous growth-theory framework. The study used cross-section data relating to a sample of 66 developing counties over three decades. The study revealed that foreign direct investment and trade contribute toward advancing economic growth in developing countries and that foreign direct investment is often the main channel through which advanced technology is transferred to developing countries [6]. Oyaromade [29] evaluated the effect of financial sector reforms on financial savings in the Nigerian economy. The study employed the error correction modeling technique, and revealed that financial reform in Nigeria had resulted in higher financial deepening and that saving had responded positively to changes in financial variables. Adewumi [14] examined the impact of foreign direct investment on economic growth in Africa using graphical and regression analysis. It was shown that the contribution of foreign direct investment to growth is positive in most of the countries but not significant. Jyun-Yi and Hsu [30] studied the effect of FDI on economic growth for 62 countries over the period 1975-2000. They found that FDI did not accelerate growth in all sampled countries. Ndambendia and Njoupouognigni [31] established that there was a long run association between aid, FDI and economic growth in 36 sub-Saharan Africa countries, and also found that foreign aid and FDI exert positive effect on economic growth, but the effect of aid is lower.
Osinubi and Amaghioneodiwe [32] used secondary data from 1970-2005 to assess the effect of foreign private investment on Nigerian economic growth. Empirical results show that foreign private investment, domestic investment growth and net export growth have significant positive impact on Nigerian economic growth.

Akinbobola [33] provide qualitative analysis of the relationship between domestic savings and economic growth in Nigeria. This study employed annual secondary data obtained from World Data Indicator (WDI), World Bank publication and Statistical Bulletin of the Central Bank of Nigeria for the period of 1970 to 2006. Descriptive Statistics were used. This study therefore concludes that the problem with Nigeria's economy is not that of mobilizing domestic savings. Erhieyovwe and Jimoh [34] assessed the direction of causality between foreign direct investment and Economic growth in Nigeria. An exploratory research design that involves a combination of ordinary Least Squares (OLS), Augmented Dickey Fuller (ADF) unit root test, and the Granger causality test to test if Foreign direct investment granger cause Economic growth in Nigeria. It was revealed that Economic growth (GDP) does not granger cause Foreign Direct Investment (FDI) in Nigeria.

Umoh Jacob and Chuku [35] investigated the relationship between foreign direct investment and economic growth in Nigeria between 1970 and 2008, argued that there is endogeneity i.e., bi-directional relationship between FDI and economic growth in Nigeria. The paper adopted both single and simultaneous equation systems to examine if there is any sort of feed-back relationship between FDI and economic growth in Nigeria. The results show that FDI and economic growth are jointly determined in Nigeria and there is positive feedback from FDI to growth and from growth to FDI. Koojaroenprasit [36] assessed the impact of foreign direct investment on economic growth of South Korea using secondary data for the period 1980-2009. Multiple regression analysis was employed in the study and indicated that human capital, employment and export also have positive and significant impact, while domestic investment has no significant impact on South Korean economic growth.

Eniekezimene [37] examined the impact of foreign portfolio investment on capital market growth: evidence from Nigeria. Ordinary Least Square method was used to analyze the data collected. It was revealed that foreign portfolio investment has a positive impact on capital market growth. Melnyk, Kubatko and Pysarenko [38] examined the impact of foreign direct investment on economic growth in postcommunism transition economies. The study used neoclassical growth theory to analyze the effect of FDI on economic growth. They found a significant FDI influence on economic growth of host countries. They concluded that in addition to the direct capital financing it supplies, FDI can be a source of valuable technology and know-how while fostering linkages with local firms, which can help to jumpstart an economy. Sulaiman and Mohammed [39] employed the Johensen cointegration and the error correction mechanism (ECM) techniques to examine the impact of 
foreign direct investment and macroeconomic stability (exchange rate and inflation rate) on the level of development of the Nigerian stock market over the period 1981-2010. The results reveal that a long run relationship exists between the variables and FDI was found to have a positive but insignificant impact on stock market development. Agrawal [40] assessed the relationship between foreign direct investment and economic growth in the five BRICS economies, namely, Brazil, Russia, India, China and South Africa over the period 1989 - 2012. Cointegration and Causality analysis were applied. The results indicate that foreign direct investment and economic growth are cointegrated at the panel level, indicating the presence of long run equilibrium relationship between them. Muntah, Khan, Haider and Ahmad [41] studied the impact of foreign direct investment on economic growth of Pakistan covering the period 1995 to 2011. The data were sourced from World Bank, Economy of Pakistan Books, Index Monde and Economic Survey of Pakistan. Regression analysis was used in the study. They found that FDI impacts positively on economic growth of Pakistan. Assiobo and Fang [42] investigated the causal relationship between Foreign Direct Investment (FDI) and Economic Growth in Togo within the period 1991-2009. To that end, they used the Grangercausality to test and determine the causal relationship between FDI and Economic Growth in Togo. Using time series data, the research found that there was a unidirectional relationship between FDI and GDP.

Aminu, El-Maude and Hamza [43] investigated the relationship between economic growth (GDP), foreign direct investment (FDI), foreign exchange rate (EXR) and openness (OPN) in Nigeria from 1981 to 2013. The paper employed Augmented Dickey-Fuller and Phillip-Perron technique in testing the unit root property of the series, Granger causality test of causation between the variables, Engel-Granger ECM technique in testing the long run adjustment speed of the model, Chow Breakpoint test, after which Jarge-Bera test of normality. The study found that there is no serial correlation among the error values, no misspecification of the model, and also that the variables are not stable throughout the period of the study and the break was found to be 1999 when the current democratic dispensation started. Adelakun [44] examined the relationship between savings, investment and economic growth. A corollary of the work is the determination of which of the inputs of production contributes more to economic growth in Nigeria. The study makes use of time series data spanning twenty nine years using error correction model. The result shows a positive relationship between savings, investment and economic growth in Nigeria. Uwubanmwen and Ogiemudia [45] examined the effect of foreign direct investment on economic growth in Nigeria using annual time series data covering the period 1979 to 2013. The data were analyzed using Error Correction Model. The results revealed that FDI has both immediate and time lag effect on Nigeria economy in the short run but has a no significant negative effect on the Nigeria economy in the long run.
Emmanuel [46] examined the effect of foreign direct investment on economic growth in Nigeria. The study used secondary data derived from the Central Bank of Nigeria statistical bulletin and publications of the National Bureau of Statistics. The study employed multiple regression technique and Gretl 1.9.8 econometric software was used for the analysis. The results showed that foreign direct investment has a positive and significant effect on gross domestic product. It was also found that exchange rate has a positive but not significant effect on gross domestic product.

The results of studies carried out on the linkage between FDI and economic growth in Nigeria are not unanimous in their submissions, studies like; Erhieyovwe and Jimoh [34] found that Economic growth (GDP) does not granger cause Foreign Direct Investment (FDI) in Nigeria. Makki and Somwaru [6] believed that sound macroeconomic policies, better stock of human capital and institutional stability are necessary preconditions for foreign direct investment -driven growth to materialize and stimulate domestic growth. Lumbila [48] and Asiedu [47] suggested that macroeconomic instability, investment restrictions, corruption and political instability have a negative impact on foreign direct investment (FDI) to Africa using time series data covering the period 1970-2003. Adewumi [14] established that the contribution of foreign direct investment to growth is positive in most of the countries but not significant. Benzuidenhout [11] found a negative relationship between FDI and growth but no relationship between aid and growth. Roman and Padureanu [49] found that FDI and capital endowments are positively correlated with GDP in Romania, but what was not expected was the fact that the human capital was negatively correlated with GDP evolution. As the authors stated, the last fact is explained by the reduction of Romanian population in 1995-2004. Pelinescu and Dulescu [50] found that direct FDI influence is still at a low level, but the indirect influence, through the increase in productivity and competitiveness is more evidenced in Romania.

The previous studies such like; Townsend [51]; Ayanwale, [9] said that the relationship between foreign direct investment and economic growth is not so clear. Carkovic and Levine [10] in their study concluded that exogenous component of FDI does not exert a robust positive influence on economic growth. Lall [13] concluded that the contribution of FDI to economic growth depends on many factors and it varies over time and from one host country to another. They therefore opined that there is the need to carry out more study on their relationship.

Considering the wide range of critical empirical studies on how foreign direct investment in Nigeria affects its economic growth and development, their results were mixed, hence inconclusive. There is need for further studies to be carried out on the effects of FDI on Nigerian economic growth.

\section{Methodology}

Ex-post fact research design and time series data which is the aspect of statistic that involves the various techniques of 
describing data collections has been adopted for the purpose of this research. This design will also enable the researcher describe and summarize the data collected for the purpose of this study and enable an in-depth knowledge about the objectives and the variables of the study.

\subsection{Population of the Study}

The population of this study was on Nigerian economic growth represented by foreign direct investment and gross domestic product from 2000 to 2017. These periods were chosen because it is within the periods that there was massive inflow and effect of foreign direct investment such as GSM.

\subsection{Sample Size and Sampling Technique}

The sample size of this study was based on the rationale for the effect of foreign direct investment on economic growth; this can mainly be measured by foreign direct investment in financial sector, oil sector, non-oil sector over by the Nigerian economy (gross domestic product) as a whole over a specified time period from 2000 to 2017.

\subsection{Method of Data Analysis}

The data collected for the study will be analyzed using
Pooled Ordinary Least Square Regression Method (OLS) and correlation with the aid of statistical e-view version 9.

Decision Rule

The decision for the hypotheses is to accept the alternative hypotheses if the F-value of the test statistic is greater than the Sig-value and to reject the alternative hypotheses if the Fvalue of the test statistic is less than the Sig- value. The hypotheses will be tested at 5\% significance level.

\subsection{Model Specification}

To establish the effect of FDI and this model was developed:

$$
\begin{gathered}
\operatorname{GDP}_{\mathrm{t}}=\beta 0+\beta 1 \text { FDIFSt }+\beta 2 \text { FDIOS }+\beta 3 \text { FDINOS } \varepsilon 1 \\
\operatorname{GDP}_{\mathrm{t}}=\beta 0+\beta 2 \text { FDIFSt }+\varepsilon 1 \\
\operatorname{GDP}_{\mathrm{t}}=\beta 0+\beta 3 \text { FDIOS }+\varepsilon 1 \\
\mathrm{GDP}_{\mathrm{t}}=\beta 0+\beta 4 \text { FDINOS }+\varepsilon 1
\end{gathered}
$$

Where

GDP $=$ Gross Domestic Product

FDIFS $=$ Foreign Direct Investment on financial sector FDIOS $=$ Foreign Direct Investment on Oil sector FDINOS =Foreign Direct Investment on Non-Oil sector

\section{Result}

\subsection{Data Analysis}

Table 1. Descriptive Statistics.

\begin{tabular}{llllll}
\hline & N & Minimum & Maximum & Mean & Std. Deviation \\
\hline GDP & 18 & 4679.21 & 89043.62 & 36217.0267 & 30393.05342 \\
FDIFS & 18 & 7.90 & 51.35 & 29.0478 & 14.43683 \\
FDIOS & 18 & 90.99 & 4022.22 & 1623.4322 & 1545.04829 \\
FDINOS & 18 & 28.89 & 1762.50 & 243.7206 & 401.20694 \\
Valid N (listwise) & 18 & & & & \\
\hline
\end{tabular}

From the descriptive statistics table, the variables indicates that the GDP has minimum and maximum values of 4679.21 and 89043.62 respectively while the standard deviation stood at 30393.05. The mean value is 36217.03. Foreign direct investment on financial sector (FDIFS) has minimum and maximum values of 7.90 and 51.35 respectively with the standard deviation of 14.44. The mean value stood at 29.05. Foreign direct investment on oil sector (FDIOS) has minimum and maximum values of 90.99 and 4022.22 respectively with the standard deviation of 1545.05 . The mean value stood at 1623.43 . Foreign direct investment on non-oil sector (FDINOS) has minimum and maximum values of 28.89 and 1762.50 respectively with the standard deviation of 401.21. The mean value stood at 243.72.

\subsection{Correlation Analysis}

In examining the association among the variables, we employed the Pearson correlation coefficient (correlation matix) and the results are presented in Table 2.

Table 2. Pearson Correlation Matrix Result of our Variables.

\begin{tabular}{lcccc}
\hline & GDP & FDIFS & FDIOS & FDINOS \\
\hline GDP & 1.000 & 0.868 & 0.897 & 0.346 \\
FDIFS & 0.868 & 1.000 & 0.875 & 0.485 \\
FDIOS & 0.897 & 0.875 & 1.000 & 0.506 \\
FDINOS & 0.346 & 0.485 & 0.506 & 1.000 \\
\hline
\end{tabular}

Source: Researcher's computation (2018) 
The use of correlation matrix in most regression analysis is to check for multicolinearity and to explore the association between the each explanatory variables and the dependent variable. Table 2 focused on the correlation between economic growth, proxy as gross domestic product (GDP) and our explanatory variables which consist of foreign direct investment on financial sector (FDIFS), foreign direct investment on oil sector (FDIOS), and foreign direct investment on non-oil sector (FDINOS). The findings from the correlation matrix table shows that all our explanatory variables were positively and weakly correlated with our dependent variable (GDP, FDIFS $=0.868$; GDP, FDIOS $=0.897$; and GDP, FDINOS=0.346).

In checking for multicolinearity, we notice that two explanatory variables were perfectly correlated. This means that there is the no absence of multicolearity problem in our model. Multicolinearity between explanatory variables results to normal signs or plausible magnitudes in the estimated model coefficient, and the unbiased of the standard errors of the coefficients.

\subsection{Test of Hypotheses}

Test of Hypotheses Formulated using Pooled Ordinary Least Square Regression Method (OLS)

However, to examine the effect relationships between the dependent variables, economic growth (GDP) and our independent variables and to also test our formulated hypotheses, we used an Ordinary Least Square (OLS) regression analysis since the data had both time series and cross sectional properties. The pooled interaction based OLS regression results obtained is presented and discussed below while detailed result is presented as appendix.

\section{Economic Growth (GDP) Model}

The Economic Growth in Nigeria (GDP) pooled OLS regression results examined the effect of foreign direct investment on economic growth in Nigeria. It investigates the effect of foreign direct investment on financial sector (FDIFS) on Nigerian economic growth, foreign direct investment on oil sector (FDIOS) on Nigerian economic growth, and foreign direct investment on non-oil sector (FDINOS) on Nigerian economic growth. The results obtained are presented in Table 3.

Table 3. EBXT Regression Result of our Sampled.

\begin{tabular}{lll}
\hline Variable & t-statistic & prob (P-value) \\
\hline FDIFS & 6.9950 & 0.090 \\
FDIOS & 8.1060 & 0.010 \\
FDINOS & 1.4740 & 0.183 \\
\hline
\end{tabular}

R-Squared 0.85

Adjusted R-squared 0.82

F-statistics 27.35800

Prob (F-statistics) 0.00 Durbin Watson .86

Source: Researcher's computation (2018): Note: * 5\%, level of significance

In testing for cause-effect relationship between the dependent and independent variable in GDP model, we reported the OLS pooled regression results in Table 3. In table 3, we observed that the R-squared and adjusted rsquared values were 0.85 and 0.82 respectively. This indicates that all the independent variables jointly explain about $83 \%$ of the systematic variations in GDP of our sampled over the period (2000-2017). The F-statistic value stood at 27.35800 and its p-value (0.00). The result further confirms the goodness of fit of our model as it is significant at $5 \%$ level. The Durbin Watson value stood at 0.86 which is approximately 1 . This result further confirms that there is no auto-correlation problem in our data. In addition to the above, the specific findings from each explanatory variable from the OLS regression model are provided as follows:

\section{Hypothesis one}

$\mathrm{H}_{\mathrm{O}}$ : Foreign Direct Investment on financial sector does not affect Gross Domestic Product in Nigeria.

Based on the t-statistics value of 6.995 and p-value of 0.00 was found to have a positive influence on our sampled economic growth (GDP) and this influence is statistically significant since its $\mathrm{p}$-value is more than 0.90 . This therefore suggests that we should accept our alternative hypothesis one $\left(\mathrm{H}_{1}\right)$ which states that foreign direct investment on financial sector has affected Nigerian economic growth. This implies that for every \#1 invested or used as capital structure mix in financial sector in Nigeria, it can leads to about 69k increase on economic growth and as such, increase earnings by the same percentage. However, this effect is statistically significant and therefore should not be ignored and can used in economic decision making.

Hypothesis Two

Ho: Foreign Direct Investment on oil sector does not affect Gross Domestic Product in Nigeria.

Based on the t-statistics value of 8.1060 and p-value of 0.010 was found to have a positive influence on our sampled economic growth (GDP) and this influence is statistically significant since its $\mathrm{p}$-value is more than 0.00 . This therefore suggests that we should accept our alternative hypothesis one $\left(\mathrm{H}_{1}\right)$ which states that foreign direct investment on oil sector has affected Nigerian economic growth. This implies that for every \#1 invested or used as capital structure mix in oil sector in Nigeria, it can leads to about $81 \mathrm{k}$ increase on economic growth and as such, increase earnings by the same percentage. However, this effect is statistically significant and therefore should not be ignored.

Hypothesis Three

Ho: Foreign Direct Investment on non-oil sector does not affect Gross Domestic Product in Nigeria.

based on the t-statistics value of 1.4740 and p-value of 0.183 was found to have a positive influence on our sampled economic growth (GDP) and this influence is statistically significant since its $\mathrm{p}$-value is more than 0.00 . This therefore suggests that we should accept our alternative hypothesis one $\left(\mathrm{H}_{1}\right)$ which states that foreign direct investment on oil sector has affected Nigerian economic growth. This implies that for every \#1 invested or used as capital structure mix in non-oil sector in Nigeria, it can leads to about $14 \mathrm{k}$ increase on economic growth and as such, increase earnings by the same percentage. However, this effect is statistically significant 
and therefore should not be ignored.

\subsection{Discussion}

The main issue in this study relates to understanding the effects and impact of foreign direct investment on the Nigerian economy as well as our ability to attract adequate amounts sufficient to accelerate the pace of our economic growth and development. Related research and studies reveals that foreign investment has been characterized as the best form of foreign finance because their package consist of finance, technology, high skilled personnel etc and that multinational corporations are highly adaptive social agents and therefore the degree to which they can help in improving economic activities through foreign direct investment will be heavily influenced by the policy choice of the host country. The findings is in line with Saibu and Keke (2014); Makki and Somwaru (2004); Umoh, Jacob and Chuku (2012), whose studies shows that foreign direct investment and trade contribute toward advancing economic growth in developing countries and that foreign direct investment is often the main channel through which advanced technology is transferred to developing countries. On the other hand that FDI and economic growth are jointly determined in Nigeria and there is positive feedback from FDI to growth and from growth to FDI.

\section{Conclusion}

The results of the findings show that foreign direct investment on financial sector, oil sector and non-oil sector has positive effect, and statistically significant on gross domestic product (GDP). In other words, the inflow of FDI into the Nigerian economy for the stipulated period this research was carried out (2000-2017), showed that FDI was a major contributor to economic growth of the nation.

From the foregoing discussion, it should be pointed out that although the government has made reasonable efforts in attracting FDI, certain economic and political circumstances prevalent in the country have hindered its inflow and its overall performance. In order to improve the climate for foreign investment in Nigeria, the Government must appreciate the fact that the basic element in any successful development strategy should be to encourage domestic investors first before going after foreign investors considering the fact that they constitute the bulk of investment activities in the economy. Thus, the most effective strategy for attracting foreign investment is to make the Nigerian economy very attractive to Nigerian investors first.

But despite the significant contribution of foreign direct investment on gross domestic product and gross domestic investments which are measures of economic growth, the contributions has not been effectively felt because of the rising rate of insecurity, corruption, socio- political instability, incomplete credibility of policy reforms etc.

\section{Recommendations}

The following were recommended to policy makers and Government, if it is desired that foreign investment contribute more to the growth and development of Nigeria.

1. Policy makers should devise strategies to increase the FDI on financial sector and offer incentive for long investing and listing on the stock market so that the main objective of the government to stimulate growth will be fulfilled.

2. It is important that the government should implement policies that will make the foreign investment on oil sector more efficient and re-position it for economic growth in Nigeria.

3. The nation's monetary authorities should develop and implement measures that will ensure that other sectors are sustained at levels that will ensure increasing level of inflow of FDI.

\section{Appendix}

Table 4. Correlation Analysis.

\begin{tabular}{|c|c|c|c|c|c|}
\hline & & GDP & FDIFS & FDIOS & FDINOS \\
\hline \multirow[t]{3}{*}{ GDP } & Pearson Correlation & 1 & $.868 * *$ & $.897 * *$ & 0.346 \\
\hline & Sig. (2-tailed) & & 0 & 0 & 0.16 \\
\hline & $\mathrm{N}$ & 18 & 18 & 18 & 18 \\
\hline \multirow[t]{3}{*}{ FDIFS } & Pearson Correlation & $.868 * *$ & 1 & $.875^{* *}$ & $.485^{*}$ \\
\hline & Sig. (2-tailed) & 0 & & 0 & 0.041 \\
\hline & $\mathrm{N}$ & 18 & 18 & 18 & 18 \\
\hline \multirow[t]{3}{*}{ FDIOS } & Pearson Correlation & $.897 * *$ & $.875^{* *}$ & 1 & $.506^{*}$ \\
\hline & Sig. (2-tailed) & 0 & 0 & & 0.032 \\
\hline & $\mathrm{N}$ & 18 & 18 & 18 & 18 \\
\hline \multirow[t]{3}{*}{ FDINOS } & $\mathrm{P}$ earson Correlation & 0.346 & $.485^{*}$ & $.506^{*}$ & 1 \\
\hline & Sig. (2-tailed) & 0.16 & 0.041 & 0.032 & \\
\hline & $\mathrm{N}$ & 18 & 18 & 18 & 18 \\
\hline
\end{tabular}

** Correlation is significant at the 0.01 level (2-tailed).

* Correlation is significant at the 0.05 level (2-tailed). 
Table 5. Regression analysis.

\begin{tabular}{|c|c|c|c|c|}
\hline \multicolumn{5}{|c|}{ Dependent Variable: EBXT } \\
\hline \multicolumn{5}{|c|}{ Method: Panel Least Squares } \\
\hline \multicolumn{5}{|c|}{ Date: 01/05/18 Time: 21:23 } \\
\hline \multicolumn{5}{|l|}{ Sample: 20002017} \\
\hline \multicolumn{5}{|l|}{ Periods included: 18} \\
\hline \multicolumn{5}{|c|}{ Cross-sections included: 15} \\
\hline \multicolumn{5}{|c|}{ Total panel (balanced) observations: 72} \\
\hline Variable & Coefficient & Std. Error & t-Statistic & Prob. \\
\hline FDIFS & 1827.561 & 261.256 & 6.99600 & 0.0900 \\
\hline FDIOS & 17.64000 & 2.17600 & 8.10600 & 0.0100 \\
\hline FDINOS & 26.19700 & 17.7700 & 1.47400 & 0.1830 \\
\hline R-squared & 0.854827 & Mean dependent var & & 36217.03 \\
\hline Adjusted R-squared & 0.823541 & S.D. dependent var & & 46363079 \\
\hline S.E. of regression & 12784.86 & Akaike info criterion & & 38.01336 \\
\hline Sum squared resid & $1.80 \mathrm{E}+17$ & Schwarz criterion & & 38.13973 \\
\hline F-statistic & 27.358312 & Durbin-Watson stat & & 0.857222 \\
\hline Prob (F-statistic) & 0.000237 & & & \\
\hline
\end{tabular}

\section{References}

[1] Udenze, O. (2014). The Effect of corruption on foreign direct investment in developing countries. The Park Place Economist, 22 (1).

[2] Cohen, S. D. (2007). Multinational corporations and foreign direct investment. Oxford University Press.

[3] Adeoye, A. (2009). Macro economic level corporate governance and fdiin emerging market: Is there Close Relationship? Journal of Economics And International Finance, 1 (12), 030-043.

[4] Ade O. A., Babatunde, H. \& Awoniyi, M. A. (2011). Corruption, foreign direct and economic growth in Nigeria: An empirical investigation. Journal of Research in International Business Management, 1 (9), 278- 292.

[5] Oba, U. O. \& Onuoha, C. B. (2013). Determinant of foreign direct investment and the Nigerian economy. American International Journal of Conter Poray Researchwww.afdb.org/fileadmin/uploads/afdb/Documents/K nowledge/25068317-En-OBAYELUS-PAPER-ONCORRUPTION-MODIFIED-VERSION.PDF. (11).

[6] Makki, S. \& Somwaru, A. (2004). Impact of foreign direct investment and trade on economic growth. American journal of agricultural economics, Vol. 86, pp. 795-801.

[7] Wang, M., (2002). Manufacturing FDI and economic growth: Evidence from Asian economies, World Economy, 29, 21-41.

[8] Liu, X. \& Burridge, P. \& Sinclair, P. J. N., (2002). Relationships Between EconomicGrowth, Foreign Direct Investment and Trade: Evidence from China" Applied Economics, 34: 1433-1440.

[9] Ayanwale, A. B. (2007). FDI and economic growth: evidence from Nigeria. African economic research consortium (AERC).

[10] Carkovic, M \& Levine, R. (2002). Does Foreign Direct Investment Accelerate Economic Growth" University of Minnesota Working Paper, Minneapolis.

[11] Benzuidenhout, H. (2009). A regional perspective in aid and
FDI in Southern Africa" North-West University Working Paper No. 147, South Africa.

[12] Akinlo, A. E. (2004). Foreign direct investment and growth in Nigeria: An empirical investigation". Journal of Policy Modeling, 26: 627-39.

[13] Lall S. (2002) FDI and development: research issues in the emerging context. Edited by Bora B. (2002) Foreign Direct Investment Research Issues. Routledge London, New York.

[14] Adewumi, S. (2006). The impact of FDI on growth in developing countries: An African Experience. Jonkoping International Business School, Sweden.

[15] United Nation, (2005). Economic development in Africa, rethinking the role of Foreign Direct Investment in United Nation, New York and Geneva. Vol 2.

[16] Ogunleye, O. (2014). Retrieved December 28, 2016, from jultika.oulu.fi/files/nbnfioulu-201406101751pdf.

[17] Barry, K. (2016). Introduction to foreign policy, Retrieved January 12, 2017, from usforeignpolicy.about.com/od/ /a/what-is-FDI.htm.

[18] Ehimare, O. A., (2011). Foreign direct investment and its effect on the Nigerian economy.

[19] Obiwona, B. (2004). Foreign Direct Investment for Africa in Financing Proper Growth. Nanrobi African Economic Research Consortium, 60-95.

[20] Shawn, G. (2016). Retrieved January 12, 2017, from Study.com/academy/lesson/what-is-foreign-direct-investmentdefinition-advantages.html

[21] Aremu, J. A. (2003). The impact of direct foreign investment in Nigeria. CBN Research Department occasional paper, No II September 2003. Lagos: University of Lagos press.

[22] Annaek, J.(2007). Foreign capital inflows an development in less developed Countries. New York: McGraw-Hill Book Company.

[23] HarunaDanja, K. (2012). Foreign direct investment and the Nigerian economy. American journal of economics. 2 (3) 3340. 
[24] UNCTAD (2009). Investment policy review, Nigeria. United Nations.

[25] Kokko, A. (2002). Globalization and FDI incentives. annual bank conference on development economics in Europe, Oslo.

[26] Markussen, J. R. \& Vernable. (1999). Foreign direct investment as a catalyst for industrial development. European economic review. 43 (2), 335-56.

[27] Borensztein, E., De Gregoria, J. \& Lee. J. (1998). How does foreign investment affect economic growth?" Journal of international economics, 45 (1): 115-35.

[28] Blomstrom, M., Lipsey, R. \& Zegan, M. (1994). "What explains developing country growth?” NBER Working Paper No. 4132. national Bureau for Economic Research, Cambridge, Massachusetts.

[29] Oyaromade, R. (2005). Financial Sector Reforms and Financial Savings in Nigeria. Selected papers for the Nigerian Economic Society Conference, 427-448.

[30] Jyun-Yi, W. \& Hsu, C. (2008). Does foreign direct investment promote economic growth? Evidence from a Threshold Regression Analysis. Economics Bulletin, 15 (12).

[31] Ndambendia, H. \& Njoupouognigni, M. (2010). Foreign aid, foreign direct investment and economic growth in SubSaharan Africa: Evidence from Pooled Mean Group Estimator" International Journal of Economics and Finance 2 (3), August.

[32] Osinubi. T. S. \& Amaghioneodiwe, L. A. (2010). Foreign private investment and economic growth in Nigeria. Review of Economic and Business Studied, 3 (1), 105-127.

[33] Akinbobola, T. (2011). Descriptive analysis of savings and growth in Nigeria economy. Journal of Economics and Sustainable Development 2 (7). ISSN 2222-1700 (Paper) ISSN 2222-2855 (Online) www.iiste.org.

[34] Erhieyovwe, E. K, \& Jimoh, E. S., (2012). Foreign direct investment granger and Nigerian growth. Journal of Innovative Research in Management and Humanities 3 (2), September, 2012. ISSN: 2141-8217. http://www.grpjournal.org/Journal/Category/JOIRMAH.aspx Printed in Nigeria. All rights reserved. (C) Global Research Publishing, 2012.

[35] Umoh O J., Jacob A O. \& Chuku A. C (2012). Foreign direct investment and economic growth in Nigeria: An analysis of the endogenous effects' Current research journal of economic theory 4 (3): 53-66, 2012.

[36] Koojaroenprasit, S. (2012): The Impact of Foreign Direct Investment on Economic Growth: A Case of South Korea. International Journal of Business and Social Science, 3 (21).

[37] Eniekezimene, F. A. (2013). The impact of foreign portfolio investment on capital market growth: evidence from Nigeria. Global business and economic research journal, 2 (8), 121129.

[38] Melnyk, L, Kubatko, O. \& Pysarenko, S. (2014). The impact of foreign direct investment on economic growth: Case of Communism Post-transition Economies. Problems and Perspectives in Management, Vol. 12, Issue 1.

[39] Sulaiman, U. M. \& Mohammed, I. (2014). Stock market development, foreign direct investment and macroeconomic stability: evidence from Nigeria. Research Journal of Finance and Accounting www.iiste.org.ISSN 2222-1697 (Paper) ISSN 2222-2847 (Online) 5 (18).

[40] Agrawal, G. (2015). Foreign direct investment and economic growth in BRICS Economies: A panel Data Analysis. Journal of Economics, Business and Management, 3 (4).

[41] Muntah, S., Khan, M., Haider, N. \& Ahmad, A. (2015). Impact of foreign direct investment on economic growth of Pakistan. American Research Journal of Business and Management, Vol. 1, Issue 1. Moss, T.

[42] Assiobo, K. M. \& Fang Q. (2015). The relationship between foreign direct investment and economic growth in Togo [1991-2009] Proceedings of the 8th International Conference on Innovation \& Management 1269 .

[43] Aminu, U., El-Maude, J. G, \& Hamza, A. P., (2015). Foreign direct investment and the growth of the Nigerian Economy. Journal of Economics and Development Studies. March 2015, 3 (1), pp. 193-211.

[44] Adelakun, O. J. (2015).An investigation of the determinants of savings and investment in Nigeria. International journal of Economics and Business 1 (2).

[45] Uwubanmwen, A. E. \& Ogiemudia, O. A. (2016). Foreign direct investment and economic growth: evidence from Nigeria. International Journal of Business and Social Sciences, 7 (3).

[46] Emmanuel, I. J. (2016). Effect of foreign direct investment on economic growth in Nigeria. European Business \& Management. 2 (2): 40-46

$\mathrm{http}: / /$ www.sciencepublishinggroup.com/j/ebm doi: 10.11648/j.ebm.20160202.14

[47] Asiedu, E. (2002). On the determinants of foreign direct investment to developing countries: Is Africa Different?" World Development, 30 (1), 107-19.

[48] Lumbila, N. K. (2005). What makes FDI work? A panel analysis of growth effect of FDI in Africa. African regional working paper series No: 8 .

[49] Roman, M. D. \& Padureanu, A. (2012). Models of Foreign Direct Investments Influence on Economic Growth: Evidence from Romania. International Journal of Trade, Economics and Finance, 3 (1).

[50] Pelinescu, E. \& Dulescu, M. (2009). The impact of foreign direct investment on the economic growth and countries' export potential. Romanian Journal of Economic Forecasting, 4 (1).

[51] Townsend I. (2003). Does foreign direct investment accelerate economic growth in less developed countries?" (online). www.stolaf.edu/people/tjf/townsend thesis. 